\title{
INTERNAL BANKING CONTROL AND AUDIT: A COMPARATIVE APPROACH IN THE ROMANIAN BANKING SECTOR
}

\author{
Adela Socol ${ }^{l}$
}

\begin{abstract}
The purpose of this paper is to realize a comparative analysis of the internal banking control and internal audit, based on the Romanian banking system case. We identify the main differences and similarities between internal control and internal audit at the level of Romanian banks. Using national regulatory framework and active banks' from Romanian behavior, we find evidence of the risk-based audit approach and the solid interdependence between the banking internal control and banking internal audit.
\end{abstract}

Key words: Internal Banking Control Policy, Internal Banking Audit Statute, Typology and role of Internal Banking Audit

JEL codes: M42, G21, G28

\section{Introduction and Research Methodology}

The starting point of this paper was an apparently discrepant assertion contained by a study issued by the Basel Committee on Banking Supervision "Strong internal control, including an internal audit function and an independent external audit, are part of sound corporate governance" (Basel Committee on Banking Supervision, 2002). Why is this discrepant assertion? We considered this a deserving affirmation worth to be studied, through the consideration of the internal banking audit belonging to the internal control. This approach puts a real sign of question in terms of interdependence and subsequently, independence of these two concepts or about the class affiliation of the internal audit to internal control.

Our research statement demonstrates the inclusion of the internal audit in the internal banking control, based on the complementarities between these managerial banking tools. We intend to study the first two mentioned concepts that contribute to the sound corporate governance of a bank and their interdependence - internal banking control and internal banking audit. We develop a multi criterion comparative analysis of the concepts, based on Romanian status in the field. The nature of the problem stems firstly from the characteristics that distinguish the internal control from the internal audit in the banking industry. The bases for the interpretation of the concepts are the national regulatory field in the area and the behavior of active banks from Romania in order to manage their risk using internal control clusters. We described the knowledge status in the field with the object of identification of key themes from previous researches and addressing this study to supply a gap under described in academic field.

The used research methodology belongs to interpretive and critical paradigm, through literature analysis and qualitative techniques and to constructivist approach, based on the interpreting research.

The internal banking control is a very delicate topic in the context of the current financial crisis, when banks need to be able to carry out their duties, even in case of severe shocks that can affect economies. The contemporary reality associated to financial crisis forced banks into reconsidering the way they have to do business by including their concern for organizing a healthy internal control. And an efficient internal banking control facilitates communication between all management structures of a bank and its operational personnel. The characteristics of an efficient

\footnotetext{
1 “1 Decembrie 1918” University of Alba Iulia, Romania, e-mail: adelasocol@yahoo.com
} 
banking control contributes to the development of communication between bank management and financial auditors, as well as those between bank management and the national banking supervision authorities.

\section{Theoretical background}

Literature on internal control and internal audit based on general non-banking companies' experience contains numerous and relevant studies, but we do not identify such generous specific approaches in the banking field. Such behavior can be explained through regulated character of internal banking control and internal audit control strongly influenced by legal regulations of the field. Under these circumstances the two studied notions moderately arouse the concern of the academic society, allowing only limited approaches.

Even since the 90's the regulated character of internal banking audit can be easily recognized among the general thematic of field studies being considered to be carried out on the basis of standing laws and regulations, which generally include also the policies and decrees of state as well as rules and by-laws of enterprises (Zhi-Di, 1997). Furthermore the internal side of audit has been initially in the public sector that is considered to be the promoter of this activity. Moreover internal audit specific to the public sector owns a higher status than their private sector counterparts (Goodwin, 2004). Recent studies have shown a significant expansion and refocus of the role of internal audit and perceptions of its effectiveness (Soh and Martinov-Bennie, 2011).

Unlike the connection between internal audit - internal control, the interaction of the financial audit with internal control or internal audit was studied from numerous perspectives such as factors that can affect external auditors' reliance on internal audit work in the current governance environment (Munro and Stewart, 2011), the financial auditor's performance in identifying internal control design weaknesses (Bierstaker and Thibodeau, 2006), a model in which a firm's owner, an auditor, and outside investors strategically interact (Pae and Yoo, 2001), implicit limitations of financial auditor's performance in determining the efficiency of internal control which unveils its impossibility of offering an absolute assurance regarding the efficacy of the internal control over financial reporting (Dănescu et. all, 2010) or clarifications regarding to fundamental concepts of auditing in Romanian practice, based on financial audit versus statutory audit approach (Mihăilescu and Mihăilescu, 2010).

A sufficient understanding of the internal control and of internal audit must be done by financial auditors in their missions (International Standard on Auditing ISA 315) and the auditor's responsibility is to communicate appropriately to those charged with governance and management deficiencies in internal control that the auditor has identified in an audit of financial statements (International Standard on Auditing ISA 265).

Rare studies applied in the field of banking emphasise the importance of bank regulation and supervision in bank-dominated financial systems (Bebenroth et. all, 2009), (VanHoose, 2008).

Modern approaches dealing with banking Risk Based Internal Audit RBIA were developed for example in the Greece case, regarding the approaches on risk assessment and audit planning such as the cyclical approach, focus on high level risks approach and fully adopted RBIA planning, which is the recommended one (Koutoupis and Tsamis, 2009).

National literature of the last years describes Risk Based Internal Audit RBIA in the context of national banking system and underlines the allowance of the auditor to make comments and advises for the banks' management regarding business risks and the implications of those risks (Dănescu et. All, 2010; Stanciu, 2008). Also, recent studies developed the subject of Basel III regulations and its adoption in the national banking field, based on new reform measures in their considered new tasks for internal banking auditors (Mihăilescu and Ducu, 2010). The authors underlined the necessity of the banking reform measures, especially in the risks' assessment process. 


\section{Romanian Realities Regarding Internal Banking Control and Internal Audit}

The short Romanian post-communist period reveals the existence of the lacunose regulatory framework regarding the internal banking control and audit. Since 2003 we can not identify a national banking regulatory settlement regarding the internal banking control or internal audit. In these circumstances banks organized their internal control and audit according to their own rules, without a common national framework. At the end of the 90's national legal regulations in this field had a general character in the context of adopting financial audit laws which enclosed the definition of internal audit and its objective. The basic settlement in the field could be considered the Governing Emergency Ordinance no. 75/1999 regarding financial audit activity that provides a definition of the internal audit and its objectives. Internal audit was defined as the activity of objective examination of all activities of an economic entity, its purpose being that of supplying an independent assessment of risk management, control management and its managing processes. A first analysis of the field of activity of internal audit reveals the exclusion of the character of consultancy specific to internal audit but which results from the general definition of internal audit supplied by IIA The Institute of Internal Auditors Internal. They consider auditing an independent, objective assurance and consulting activity designed to add value and improve an organization's operations. It helps an organization accomplish its objectives by bringing a systematic, disciplined approach to evaluate and improve the effectiveness of risk management, control, and governance processes.

The legislative 'oversight' initially included by national regulations in this field of activity were corrected through a regulation specific to the banking field, issued in 2003 (NBR, Norm no. 17/2003) and which positions internal banking audit in such a way that it contributes to fulfilling the objective of a bank through presenting a systematic and disciplinary approach of assessing and improving internal control system efficiency, risk and managing administration processes from credit institutions, inside audit commitment or, respectively, through supplying consultancy services according to the statute of internal audit.

In The Norm of National Bank of Romania no. 17/2003, we can find mentioned for the first time in national legislation the idea of organizing internal audit as a component of the monitoring activity of the internal control system. Moreover, it is mentioned that internal audit contributes at assessing adequacy of the competent authorities of own funds depending on the risks that expose credit institutions for insuring an independent assessment of adequacy of established politics and procedures and of the way in which they are respected.

This mentioned legal regulation defines also conceptually internal banking control as a continuous process that has the contribution of the managing board as well as the personnel of credit institutions through which a reasonable insurance is supplied regarding reaching objectives of internal control that consist of:

a) Progress of activities in conditions of high efficiency and efficacy;

b) Supply credible, relevant, complete and appropriate information to the departments implied in decision making inside the credit institution and external users of information;

c) Certifying the conformity of activities of credit institutions with the legal frame and own politics and procedures.

Between 2003 and June 2010, banking institutions have benefited from minimal legislative guidelines regarding internal and external processes thanks to The Norm of National Bank of Romania no. 17/2003. Now, active banking societies from Romania have to apply a regulatory settlement regarding the administration framework of the credit institutions' activity, internal process of evaluation of capital adequacy to risks and the conditions of outsourcing their activities (NBR, Regulation no. 18/2009).

The active provision from end of July 2010 introduces the term of Internal Capital Adequacy Assessment Process (ICAAP) as component of the administrative frame of activities of 
the credit institution that is aimed at their managing team for assuring identification, assessment, aggregation and adequate monitoring of risks of the credit institution, owning internal equity suitable to risk profile and using and developing solid risk administration systems.

In this respect the managing structure of a credit institution has to develop and maintain a solid internal control system. In order to implement an efficient and comprising internal control system for all fields of activity of a credit institution, it has to organize at least the three basic functions of internal control system: risk control, compliance and internal audit.

This law mentions that banks will organize the internal audit function according to the regulations issued by Chamber of Financial Auditors of Romania. This chamber has established ever since 2007 a set of Internal Audit Norms (CFAR, Decision no. 88/2007) that include:

a) Internal audit standards elaborated and published by Institute of Internal Auditors IIA - (international authority for developing best practices in this field) adopted by Chamber of Financial Auditors of Romania as national internal audit norms;

b) Procedures regarding General frame for developing internal audit missions.

\section{A Comparative Study between Internal Banking Control and Internal Banking Audit}

We intend to develop and describe the basic features of these mentioned concepts, comparing them by using a full set of already identified variables that have to obey at least to these aspects: organization way and involved structures, exerting ways, objectives, reporting activities and instruments.

Table no. 1

A Multi-criteria Analysis of Internal Banking Control versus Internal Banking Audit

\begin{tabular}{|c|c|c|}
\hline Criterion & Internal Banking Audit & Internal Banking Control \\
\hline $\begin{array}{l}\text { Organizational } \\
\text { Status }\end{array}$ & $\begin{array}{l}\text { Audit function is organized as a function of } \\
\text { the internal control of a credit institution } \\
\text { together with risk control and compliance } \\
\text { function. } \\
\text { It is an independent and objective activity of } \\
\text { assuring and consulting conceived to add } \\
\text { value and improve bank activities. } \\
\text { It helps the bank with fulfill its objectives } \\
\text { by supplying a systematic disciplined } \\
\text { method of assessment and improvement of } \\
\text { efficiency of risk management, control } \\
\text { management and corporate governing } \\
\text { processes. }\end{array}$ & $\begin{array}{l}\text { Internal control is a continuous process } \\
\text { designed to supply a reasonable insurance for } \\
\text { fulfilling performance, information and } \\
\text { conformity objectives and which, in order to be } \\
\text { effective, needs implantation of the following } 3 \\
\text { functions: risk control function, conformity } \\
\text { function and internal audit function. } \\
\text { Internal control also includes organizing } \\
\text { accounting, management of the information, } \\
\text { risk assessment and the systems that measure } \\
\text { them. }\end{array}$ \\
\hline $\begin{array}{l}\text { Involved structures } \\
\text { Ways of applying }\end{array}$ & $\begin{array}{l}\text { Internal audit is organized taking into } \\
\text { consideration a Statute of the internal audit } \\
\text { that is in accordance with regulations issued } \\
\text { by Financial Auditing Chamber from } \\
\text { Romania, in house (through the Specialty } \\
\text { department of the bank, internal audit } \\
\text { inspectors) or by outsourcing. } \\
\text { There is an Audit Committee responsible } \\
\text { with: } \\
\text { a) Supervising the internal auditors and } \\
\text { financial auditors; } \\
\text { b) Approving or submitting for approval } \\
\text { addressed to the executives having as } \\
\text { function supervision, payment and } \\
\text { revocation of financial auditor. } \\
\text { c) Revising and approving the sector of the } \\
\text { audit and frequency of audit } \\
\text { commitment } \\
\text { d) Receiving audit reports } \\
\text { e) Insuring that the executives take all }\end{array}$ & $\begin{array}{l}\text { Control activities are organized at each } \\
\text { operational level of the bank and are part of } \\
\text { daily activities of the bank. } \\
\text { Ways of applying: } \\
\text { Level } 1 \text { - Permanent control } \\
\text { Level } 2 \text { - Subsequent internal control in situ } \\
\text { Level } 3 \text { - Supervising }\end{array}$ \\
\hline
\end{tabular}




\begin{tabular}{|c|c|c|}
\hline Criterion & Internal Banking Audit & Internal Banking Control \\
\hline & $\begin{array}{l}\text { necessary correction measures for } \\
\text { resolving deficiencies identified during } \\
\text { the control and conformity activity, as } \\
\text { well as other problems identified by } \\
\text { auditors }\end{array}$ & \\
\hline Objectives & $\begin{array}{l}\text { a) Assuring that the politics and processes } \\
\text { of credit institutions are respected } \\
\text { within all activities and structures } \\
\text { b) Revising control politics, processes and } \\
\text { mechanisms in such a way that they stay } \\
\text { sufficient and appropriated to their } \\
\text { specific activity. }\end{array}$ & $\begin{array}{l}\text { Performance objectives (effectiveness and } \\
\text { efficiency of all activities developed), } \\
\text { information objectives (legitimacy, integrity } \\
\text { and supplying in due time financial information } \\
\text { and other information needed by the } \\
\text { management) and conformity objectives } \\
\text { (conformity with applicable regulations as well } \\
\text { as with internal politics and procedures). }\end{array}$ \\
\hline Activities & $\begin{array}{l}\text { Assuring that politics and procedures are } \\
\text { respected at all levels of the bank } \\
\text { - Revising politics, processes and control } \\
\text { mechanisms already existing in the bank } \\
\text { - Analyze the quality of all controls made } \\
\text { within the bank from the point of view of } \\
\text { effectiveness and efficiency } \\
\text { - Expressing recommendations referring to } \\
\text { the internal control system } \\
\text { - Access to all documents and records } \\
\text { needed for carrying out activities } \\
\text { - Has a methodology of risk identification } \\
\text { - Performs audit of internal activities as well } \\
\text { as those outsourced }\end{array}$ & $\begin{array}{l}\text { Control activities include at least one of the } \\
\text { following: } \\
\text { a) Analysis at the level of management } \\
\text { structures; } \\
\text { b) Operative analysis at the level of credit } \\
\text { institutions structures; } \\
\text { c) Factual controls that have in view limiting } \\
\text { the access to assets - for example: titles, } \\
\text { cash - limiting the access to clients accounts } \\
\text { etc.; } \\
\text { d) Analyze inclusion in the limits imposed to } \\
\text { risk exposure and follow up of the way in } \\
\text { which non-conformity situations } \\
\text { resolved; } \\
\text { e) Approvals and authorizations in the case of } \\
\text { operations that exceed certain amounts; } \\
\text { f) Inspection - the } 4 \text {-eye principle: segregation } \\
\text { of various functions, cross- checking, dual } \\
\text { control of assets, double signatures; } \\
\text { g) Inspections of performed transactions and } \\
\text { reconciliations, especially in cases where } \\
\text { there are differences between the assessing } \\
\text { methodologies or systems used by structures } \\
\text { responsible with start up of transactions - } \\
\text { front office - and the structures responsible } \\
\text { with registration and monitoring of } \\
\text { initialized transactions - back office }\end{array}$ \\
\hline Reporting & $\begin{array}{l}\text { The internal audit function must have } \\
\text { unlimited access to the management } \\
\text { structure and to the audit committee, as well } \\
\text { as to relevant documents and information } \\
\text { from all fields of activity. } \\
\text { Any recommendations made by internal } \\
\text { audit for significant remediation of internal } \\
\text { controls must be directly reported to the } \\
\text { management structures of the credit } \\
\text { institution. } \\
\text { All recommendations made by internal } \\
\text { audit must be the object of a follow up } \\
\text { procedure by the management structure } \\
\text { having as aim solution assurance and, } \\
\text { respectively, reporting. }\end{array}$ & $\begin{array}{l}\text { Monitoring effectiveness of the internal control } \\
\text { system must be part of daily activities of credit } \\
\text { institutions and must include separate } \\
\text { assessment of the internal control system in } \\
\text { general. } \\
\text { Deficiencies identified in relation to the } \\
\text { internal control system must be acknowledged } \\
\text { immediately to the persons in medium leading } \\
\text { positions who have to take measures to } \\
\text { promptly correct them. } \\
\text { Major deficiencies of internal control system } \\
\text { must be acknowledged immediately to the } \\
\text { persons in leading positions and executives in } \\
\text { supervision positions of credit institutions. } \\
\text { Monitoring the efficiency of internal control } \\
\text { system will be done by the personnel } \\
\text { responsible for each structure of the credit } \\
\text { institutions as well as for internal audit. }\end{array}$ \\
\hline
\end{tabular}

Source: processing the author based on effective national legislation and bank behavior in this field. 
Here we come with details of the ways of applying internal banking control through which bank personnel must assure the control activities according to the following levels:

Table no. 2

\section{Levels of applying internal banking control}

\begin{tabular}{|c|c|c|c|c|}
\hline \multicolumn{3}{|c|}{$\begin{array}{l}\text { Level } 1 \text { - Permanent control is the summary of internal norms that are } \\
\text { permanently applied for guaranteeing, al operational level, regularity, } \\
\text { security and verity of realized operations. }\end{array}$} & \multirow{2}{*}{$\begin{array}{l}\text { Level } 2- \\
\text { Subsequently } \\
\text { Internal control } \\
\text { on sight }\end{array}$} & \multirow{2}{*}{$\begin{array}{l}\text { Level } 3 \\
\text { Supervision is done } \\
\text { by the executive } \\
\text { management and } \\
\text { Administration } \\
\text { board, within the } \\
\text { periodical analysis } \\
\text { for efficiency and } \\
\text { efficacity of the } \\
\text { internal control } \\
\text { system. }\end{array}$} \\
\hline $\begin{array}{l}\text { a) Permanent control may } \\
\text { be a preventive control, } \\
\text { simultaneously or } \\
\text { subsequent to performing } \\
\text { operations and is made of: } \\
\text { a applying work } \\
\text { attributions according to } \\
\text { job description and OOR } \\
\text { Organization and } \\
\text { Operating Rulebook by } \\
\text { execution personnel, with } \\
\text { strict fulfillment of specific } \\
\text { tasks enclosed by effective } \\
\text { internal norms; } \\
\text { o applying supervision by } \\
\text { persons named in specific } \\
\text { internal norms, as well as } \\
\text { by hierarchic superiors. }\end{array}$ & $\begin{array}{l}\text { b) Hierarchic control } \\
\text { applied by the operative } \\
\text { bank management has as } \\
\text { objectiver checking } \\
\text { effective internal norms } \\
\text { application as well as } \\
\text { permanent control } \\
\text { efficiency. }\end{array}$ & $\begin{array}{l}\text { c) Preventive } \\
\text { control on desk is } \\
\text { applied by a } \\
\text { control structure } \\
\text { like Department } \\
\text { of Internal } \\
\text { Control. }\end{array}$ & & \\
\hline
\end{tabular}

Source: processing the author based on effective national legislation and bank behavior in this field.

The analysis does not give enough importance to the human factor implied in the internal banking control activity. We consider necessary further explanations regarding the way applying control by the bank employees because internal control activities must be part of daily activities of credit institutions. The specific of banking activities imposes that bank personnel would not have exclusive control over one/ some operations summing two or more of the following functions: decision function, values and goods management function, maintaining record function and control function. The types of activities that must be definitely separated include: trading and clearing, management of values and maintaining accounting record of them; authorizing transactions and registering them. It is absolutely necessary separating incompatible activities like:

- Personnel responsible with registration of transactions does not have any attributes in authorizing them;

- Separating front-office activities from back-office activities both at the level of central bank and agencies/ branch office;

- Separating the activities of credit documentation analysis from the activity of implementation and monitoring

\section{Conclusions}

We found that the relationship between internal banking audit and internal banking control is a very complex and intimate one, generated especially by legislative demands in field. They impose to the banks organizing the audit functions as a component of the internal control system and lead to interdependency of the studied concepts.

Practice is the one validating this interdependency and the key organizational structure of the relationship between internal banking audit and internal banking control is the Administration Board which creates and maintains an adequate and efficient internal control system by two means: the Audit Committee and the executive management. The Administration Board, through the Audit 
Committee, assesses the internal control system assuring in this way the development and support of a solid internal control system. The Audit Committee is a consultative executive with the Administration Board and its objective is coordination of implementation of the internal audit system for improving unit function from the bank and determining a more efficient and rational function of the bank as well as for assuring consultancy and assistance in managing the bank from the point of view of the internal audit. The executive managing team applies the strategy and politics approved by is the Administration Board; coordinates identification, assessment, monitoring and control processes regarding the risk that threaten the bank, maintains a good organizational structure that clearly defines responsibility, competence and reporting relationships; makes sure that assigned responsibilities are accomplished efficiently; establishes appropriated internal control politics; monitors the degree of adequacy and efficiency of the internal control system.

The administration board and executive management promotes high standards of ethics and integrity, establish an institutional culture highlighting and demonstrating the importance of internal control on all organizational levels. All employees of the bank must be aware of the role they have in the internal control system and must be actively involved in this process.

A key element of a strong internal control system is realization by each employee of necessity of fulfilling his/her responsibilities in an efficient manner and of communicating to leading management any problem that may have appeared during operations, any infringement of the Code of Conduct, internal norms or observed illegal actions.

\section{References}

1. Basel Committee on Banking Supervision, 2002. Internal audit in banks and the supervisor's relationship with auditors: A survey

2. Bebenroth R., Dietrich D., Vollmer U., 2009. Bank Regulation and Supervision in Bankdominated Financial Systems: A Comparison between Japan and Germany, European Journal of Law and Economics, Issue 27, pp. 177-209

3. Bierstaker J.L, Thibodeau J.C., 2006. The Effect on Format and Experience on Internal Control Evaluation, Managerial Auditing Journal, Vol. 21, No. 9, pp. 877-891

4. Camera Auditorilor Financiari din România, 2007. Hotărâre nr. 88 pentru aprobarea Normelor de Audit Intern, available online at http://www.cafr.ro/legislatie.php?id=13

5. Dănescu T, Şandru R., Dănescu A.C., Muntean A., 2010. The Internal Control over Financial Reporting - Identity Crisis of Financial Information Published by Companies in Romania, Applied Economics Business and Development, pp. 75-80

6. Dănescu T, Oltean (Muntean) A., Şandru R., 2010. Risks Based Internal Audit: Perspectives offered to Corporations and Banks, Annales Universitatis Apulensis Series Oeconomica, 12(1), pp. 231-237

7. Goodwin J., 2004. A Comparison of Internal Audit in the Private and Public Sector, Managerial Auditing Journal, Vol. 19, No. 5, pp. 640-650

8. International Auditing and Assurance Standards Board (IAASB), International Standard on Auditing 315, Identifying and Assessing the Risks of Material Misstatement through Understanding the Entity and its Environment.

9. International Auditing and Assurance Standards Board (IAASB), International Standard on Auditing 265, Communicating Deficiencies in Internal Control to Those Charged with Governance and Management.

10. Koutoupis A.G., Tsamis A., 2009. Risk based Internal Auditing within Greek Banks: a Case Study Approach, Journal of Managerial Governance, Issue 13, pp. 101-130

11. Mihăilescu I., Mihăilescu C.T., 2010. Financial Audit versus Statutory Audit. Required Clarifications within the Professional Practice, Financial Audit Journal, No. 2, pp. 3-9 
12. Mihăilescu C.T., Ducu C., 2010. Internal Audit Regulations and Developments within Credit Institutions, Proceedings of the International Workshop "Advanced Research and Trends in Accounting, Audit and Finance ICMEA", Aeternitas Publishing House, pp. 639649

13. Munro L., Stewart J., 2011. External Auditors' Reliance on Internal Auditing: Further Evidence, Managerial Auditing Journal, Vol. 26, No. 6, pp. 464-481

14. Norm of the National Bank of Romania no. 17 from 2003 regarding the organization and internal control of the activities in a credit institution and managing the significant risks, as well as organizing and carrying the internal audit activity of the credit institutions, published in Official Gazette no. 566/2004

15. Pae S., Yoo S.W., 2001. Strategic Interaction in Auditing: An Analysis of Auditors' Legal Liability, Internal Control System Quality, and Audit Effort, The Accounting Review, Vol. 76, No. 3, pp. 333-356

16. Regulation of the National Bank of Romania no. 18/2009 on governance arrangements of the credit institutions, internal capital adequacy assessment process and the conditions for outsourcing their activities, published in Official Gazette no. 630/2009

17. Soh D.S.B., Martinov-Bennie N., 2011. The Internal Audit Function. Perceptions on Internal Audit Roles, Effectiveness and Evaluation, Managerial Auditing Journal, Vol. 26, No. 7, pp. 605-622.

18. Stanciu V., 2008. Internal Audit Approach in Banks, Scientific Annals of the Al. I. Cuza University of Iaşi, Vol. 55, pp. 137-142

19. Van Hoose D.D., 2008. Bank Capital Regulation, Economic Stability, and Monetary Policy: What does the academic literature tell us?, Atlantic Economic Journal, Issue 36, pp. 1-14

20. Zhi-Di X., 1997. Bank of China surveillance study design for internal audit, Managerial Auditing Journal, Vol. 12, Issue 4-5, pp. 251-257 